\title{
DELINEATING THE JURASSIC TO MID-CRETACEOUS PART OF THE PACIFIC APPARENT POLAR WANDER PATH
}

\author{
DCP Masalu \\ Institute of Marine Sciences, University of Dar es Salaam, \\ Mizingani Road, PO Box 668, Zanzibar, Tanzania \\ Phone/Fax +255 242232128 \\ Email: masalu@ims.udsm.ac.tz
}

\begin{abstract}
The Jurassic to Mid-Cretaceous apparent polar wander path of the Pacific plate irrespective of ages have been delineated. Two poles have been established: one pole, which is relatively older than the other, is at $75.01^{\circ} \mathrm{N} / 287.5^{\circ} \mathrm{E}\left(\alpha_{95}=6.9^{\circ}\right)$ and the other pole is at $61.0^{\circ} \mathrm{N}^{\circ} / 304.7^{\circ} \mathrm{E}\left(\alpha_{95}\right.$ $\left.=4.5^{\circ}\right)$. These results indicate that the Pacific plate drifted southward during the Jurassic to Early-Cretaceous period. Additionally, the results demonstrate that there is an apparent consistent correspondence between changes of plate motion and significant shifts of the Jurassic to Mid-Cretaceous apparent polar wander path.
\end{abstract}

\section{INTRODUCTION}

Apparent polar wander paths (APWP) are one of the primary tools of paleomagnetic research. However, because of the inherent difficulty in obtaining fully oriented samples from beneath the ocean, oceanic plates, including the Pacific plate, until recently did not have well defined APWPs. Consequently, oceanic plates were difficult to include in studies of global tectonics and paleomagnetic field. This problem was solved by the formulation of the seamount paleomagnetism technique (Talwani 1965, Plouff 1976, Parker et al. 1987). Following this, Sager and Pringle (1988) using mainly seamount paleomagnetic data delineated a well defined Pacific APWP for MidCretaceous to Present which covers only about half of the lifetime of the Pacific plate. Delineation of the older part of the Pacific APWP has been difficulty due to the scarcity of paleomagnetic data of that age, and the fact that among the available data only few have reliable ages. Efforts to improve the defined Pacific APWP as well as extend it into the older past have continued as more reliable data and good technology becomes available (e.g., Sager and Koppers 2000). Sager and Koppers (2000) used 27 paleomagnetic poles from seamounts dated by ${ }^{40} \mathrm{Ar} /{ }^{39} \mathrm{Ar}$ to revise the
Pacific APWP. The new APWP is complex than that of Sager and Pringle (1988) and does not have a sharp bend at 82Ma. Similarly, Sager (2003) computed a new chron C33r pole for the Pacific APWP using basalt and sediment core data from Deep Sea Drilling Project (DSDP) and Ocean Drilling Program (ODP). For the purpose of this work the Pacific APWP of Sager and Pringle (1988) is used mainly because of its simple shape and the fact that this work is dealing with the older unknown part of the APWP.

The importance of a complete defined Pacific APWP cannot be overemphasized. The Pacific plate is known to have a very long and varying tectonic evolution history (Nakanishi et al. 1992). This is the largest oceanic plate, covering about $20 \%$ of the earth's surface and abuts six major and several minor plates, and thus the key to the understanding of the tectonic evolution of the Pacific basin and adjacent plates. A complete defined Pacific APWP would be a useful benchmark for paleomagnetic research of both the Pacific plate and the adjacent plates. In addition to being useful in unraveling tectonic evolution history of Pacific basin plates, because many Pacific seamounts that gave reliable poles are not 
dated, the APWP will serve as a bench mark for dating these seamounts by comparing them with it.

An attempt has been made in this work to delineate the Pacific APWP for Jurassic to Mid-Cretaceous Period. The scarcity of paleomagnetic data with reliable dates for Jurassic and Early-Cretaceous Period, calls on any attempt to delineate the APWP for that age to employ methods that do not directly depend on availability of dated paleomagnetic data. Consequently, in this paper a systematic delineation of the Pacific APWP for Jurassic to Mid-Cretaceous Period, which does not depend on availability of dated paleomagnetic data for that period is done.

The data used in this study is a combination of the compilation of Pacific seamount paleomagnetic data with reliable poles of Sager (1992) and Masalu (1994).

\section{METHODS}

Because of the scarcity of reliable dates for Jurassic and Early-Cretaceous seamounts, the major inherent difficult for this study is how to isolate seamount poles of that period. This problem was systematically approached as follows. First, from the databases used in this study, only all seamounts on Jurassic seafloor older than M1 (Fig. 1) were selected which gave a total of 59 seamounts (Table 1 ). It is known that the Jurassic seafloor older than M1 contains Jurassic plus later seamounts. Thus, the selected seamounts gave a scattering of poles from Jurassic and later (Fig. 2). Second, all poles within a distance of the known MidCretaceous to Present Pacific APWP on the right of the dashed line in Fig. 2 traced following the $95 \%$ confidence circles of the Pacific APWP of Sager and Koppers (2000) were omitted. Few poles remained on the left of the dashed line which may be due to some errors or it could be the APWP. However, errors are unlikely to put many poles in any one area (i.e., the scatter should be more random). So, the remaining poles are most probably Jurassic to EarlyCretaceous. A mean pole (Fisher 1953) for Jurassic to Early-Cretaceous of the Pacific APWP based on all the isolated/remaining poles (Fig. 2) is at $63.6^{\circ} \mathrm{N} / 303.5^{\circ} \mathrm{E}\left(\alpha_{95}=\right.$ $\left.5.1^{\circ}\right)$. However, this pole may be misleading because the remaining Jurassic to Early-Cretaceous poles are scattered over a wide area from about $50^{\circ} \mathrm{N}$ to $75^{\circ} \mathrm{N}$. To go around this obstacle the relative ageing of the seamounts was determined by computing their northward drift amounts (Masalu 1994, Masalu et al. 1997).

Northward drift is computed as the present latitude of a seamount minus its paleolatitude. Masalu (1994) and Masalu et al. (1997) found that Pacific seamounts that are considered older than Mid-Cretaceous display northward drift amounts smaller than those of Mid- to Late-Cretaceous. They suggested that the observation indicates that the seamounts drifted southward when they formed probably during the Jurassic to Early-Cretaceous Period (Larson and Lowrie 1975, Jarrard and Sasajima 1980, Cox and Gordon 1984, Sager and Pringle 1988). The concept of northward drift implies that the smaller the northward drift amounts the older the seamount is (i.e. the more south the seamount drifted). Thus, variations of northward drift amounts of Jurassic to EarlyCretaceous seamounts can give us an idea of their relative age (Masalu 1994). However, the method of analyzing northward drift to investigate relative ageing of seamounts must be used cautiously because in addition to differences in age, the northward drift may also vary depending on the location of the Euler pole of the concerned plate, and erroneous paleomagnetic data. If the Euler pole is far away, then this method works well, but if the Euler pole is very close it can give misleading results. As for this study, the Pacific plate is known to have migrated northward and west-northwestward and to have undergone little rotations (Henderson 1985, Engebretson et al. 1985, Duncan and Clague 1985). This implies that the effect of the location of the Euler poles 
for the Pacific plate will only minimally affect computed northward drift of the seamounts. Nevertheless, it is important to mention here that currently there is resurgence of active research on the absolute motion of the Pacific plate (e.g., Wessel et al. 2006, Steinberger et al. 2004) following strong evidence for the migration of hotspots (e.g., Duncan et al. 2004, Tarduno et al. 2003, Tarduno 2007). These new works are poised to change our understanding of the tectonics of the Pacific plate.

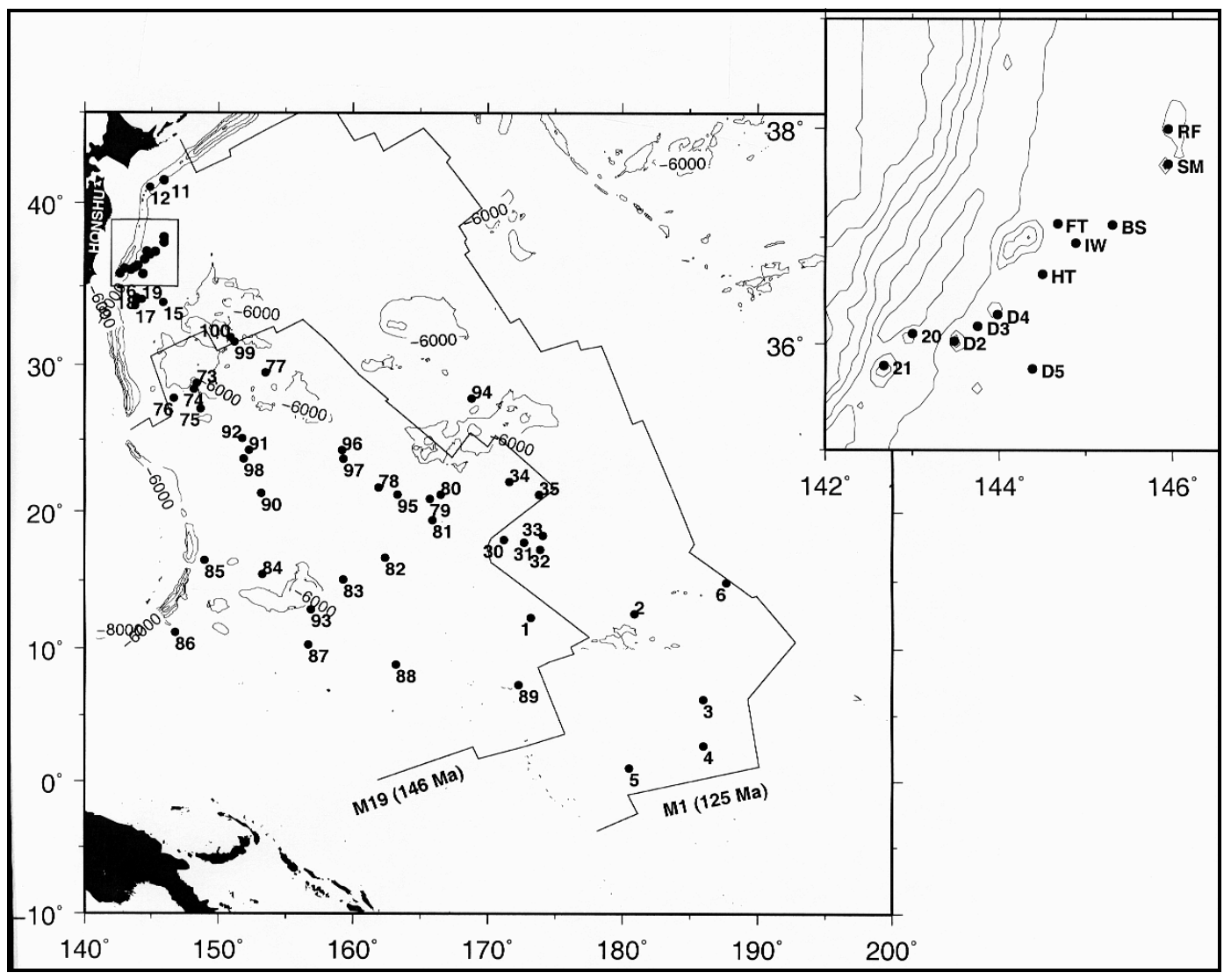

Figure 1: Map of the Pacific Ocean basin showing the locations of seamounts on seafloor older that M1 (123Ma). Insert box as detailed on the top right is the Joban seamount chain. Seamount symbols are as detailed in Table 1. 
Masalu-Delineating the Jurassic to Mid-Cretaceous Part ...

Table 1: $\quad$ Pacific seamounts on seafloor older than M1.

\begin{tabular}{|c|c|c|c|c|c|c|c|c|c|c|c|c|c|c|c|c|c|}
\hline \multirow[b]{2}{*}{ ID } & & \multicolumn{2}{|c|}{ Location } & \multicolumn{2}{|c|}{$\begin{array}{l}\text { Pole } \\
\end{array}$} & \multirow[b]{2}{*}{ Inc. } & & \multirow{2}{*}{$\begin{array}{l}\text { Inten. } \\
\text { U/NU }\end{array}$} & \multirow[b]{2}{*}{ GRF } & \multicolumn{2}{|r|}{ Age } & \multicolumn{3}{|c|}{$\begin{array}{l}\text { Error Ellipse } \\
\end{array}$} & \multirow{3}{*}{ Type } & \multicolumn{2}{|c|}{ Reference } \\
\hline & & $\begin{array}{l}\text { Lat. } \\
\left.{ }^{\circ} \mathbf{N}\right)\end{array}$ & $\begin{array}{l}\text { Lon } \\
\left({ }^{\circ} \text { E) }\right.\end{array}$ & $\begin{array}{l}\text { Lat. } \\
\text { (ON) }\end{array}$ & $\begin{array}{l}\text { Lon } \\
\left({ }^{\circ} \mathrm{E}\right)\end{array}$ & & & & & Pmag & Other & Maj & Min & Az & & Pmag & Age \\
\hline & $\frac{\text { Name }}{\text { Magnet }}$ & $\frac{(\mathrm{N})}{12.3}$ & 173.2 & (N) 61 & (E) 31.2 & $\frac{1 \text { inc. }}{-20.9}$ & & & $\frac{G K F}{3.9}$ & & & & & & & & \\
\hline & $\begin{array}{l}\text { Dixon } \\
\text { Dixulet }\end{array}$ & 12.6 & 180.9 & $\begin{array}{l}01 \\
68\end{array}$ & 1 & $\begin{array}{l}-20.9 \\
-18.9\end{array}$ & $\begin{array}{r}342.3 \\
0\end{array}$ & $\begin{array}{l}9.5 \\
6.7\end{array}$ & $\begin{array}{l}3.9 \\
5.6\end{array}$ & $\begin{array}{l}\text { LK } \\
\text { LK }\end{array}$ & & & & & $\begin{array}{l}\mathrm{L} \\
\mathrm{L}\end{array}$ & & \\
\hline 3 & 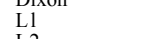 & $\begin{array}{l}12.0 \\
6.2\end{array}$ & $\begin{array}{l}1806 \\
186\end{array}$ & 69.7 & 27.5 & $\begin{array}{l}-18.93 \\
-24.3\end{array}$ & 352.5 & 7.11 & $\begin{array}{l}2.0 \\
2.8\end{array}$ & $\begin{array}{ll}\mathrm{LK} \\
\mathrm{LK}\end{array}$ & & & & & $\mathrm{L}$ & 3 & \\
\hline $\begin{array}{l}4 \\
5\end{array}$ & $\mathrm{~L} 2$ & & 186 & $\begin{array}{l}66.5 \\
54 .\end{array}$ & $\begin{array}{r}5.5 \\
3241\end{array}$ & 37.3 & & 7.5 & 3.8 & LK & & & & & $\mathrm{L}$ & & \\
\hline 6 & $\begin{array}{l}\text { L3 } \\
\text { Unnamed }\end{array}$ & 14.9 & $\begin{array}{l}180.3 \\
187.7\end{array}$ & $\begin{array}{r}54.9 \\
55\end{array}$ & $\begin{array}{r}324.1 \\
1.8\end{array}$ & $\begin{array}{l}-43.1 \\
-35.9\end{array}$ & $\begin{array}{r}22.4 \\
3.6\end{array}$ & $\begin{array}{r}10.5 \\
3.8\end{array}$ & $\begin{array}{r}4.3 \\
2\end{array}$ & $\begin{array}{l}\text { MK } \\
\text { MK }\end{array}$ & 83P & & & & $\begin{array}{l}\mathrm{L} \\
\mathrm{L}\end{array}$ & 4 & 1 \\
\hline & Unnamed & & & 49.4 & 337.1 & 2.4 & 352.8 & 156 & 1.8 & MK & & & & & $\mathrm{L}$ & 6 & \\
\hline 12 & Erimo & 40.9 & 144.9 & 69 & 321 & 36 & & 5.8 & 5.7 & $\mathrm{EK}$ & $130 \mathrm{~L}$ & & & & $\mathrm{~L}$ & & 2 \\
\hline 13 & Ryofu & 38 & & 53 & 352.7 & 2.2 & 343.2 & 9.4 & 3.4 & & & & & & $\mathrm{~L}$ & & \\
\hline 14 & Unnamed & 36 & 143.5 & $\begin{array}{l}46.2 \\
40.9\end{array}$ & $\begin{array}{r}353.9 \\
21.6\end{array}$ & & $\begin{array}{l}341.1 \\
320\end{array}$ & $\begin{array}{l}4.1 .2 \\
8.3\end{array}$ & $\begin{array}{r}13 \\
2.7\end{array}$ & ${ }_{\mathrm{K}}^{\mathrm{MK}}$ & & 7 & 2.4 & 113 & L & $\begin{array}{l}8 \\
3\end{array}$ & \\
\hline 15 & Maiko & 34 & 145.9 & 50.5 & 327.1 & -10.9 & 359.3 & 12.2 & 4.7 & & & & & & $\mathrm{~L}$ & & \\
\hline 16 & Takuvo-Daini & 34.3 & 143.9 & $\begin{array}{l}53.1 \\
75.4\end{array}$ & $\begin{array}{l}321.1 \\
315.7\end{array}$ & $\begin{array}{l}-5.5 \\
35.8\end{array}$ & $\begin{array}{l}2.9 \\
2.2\end{array}$ & $\begin{array}{r}13.4 / 4.2 \\
502.6\end{array}$ & & $\stackrel{\mathrm{MK}}{\mathrm{EK}}$ & $>98 \mathrm{~F}$ & $\begin{array}{l}4.7 \\
5.6\end{array}$ & 2.1 & $\begin{array}{l}113 \\
88\end{array}$ & $\begin{array}{l}\mathrm{S} \\
\mathrm{S}\end{array}$ & $\begin{array}{l}5 \\
5 \\
\end{array}$ & \\
\hline 17 & Jenson & 33.8 & 143.8 & 55 & 340.5 & 0.9 & 350.7 & $19.4 / 8.3$ & & MK & & 5.9 & 2.6 & 102 & S & 5 & \\
\hline 18 & $\begin{array}{l}\text { Jenson I } \\
\text { Seiko }\end{array}$ & 34.1 & $\begin{array}{l}143.9 \\
144.3\end{array}$ & $\begin{array}{l}68.6 \\
582\end{array}$ & 341.7 & $\begin{array}{l}25.7 \\
4.9\end{array}$ & 353.3 & $\begin{array}{l}23.1 / 9.6 \\
111 / 6.8\end{array}$ & & LK & 1024 & 18 & $\begin{array}{l}8.5 \\
19\end{array}$ & 103 & $\underset{\mathrm{S}}{\mathrm{S}}$ & 5 & $3+3+2$ \\
\hline 20 & Katori & 36.1 & $\begin{array}{r}144.3 \\
143\end{array}$ & 59.9 & 354.1 & 18.3 & 344.8 & $\begin{array}{r}11.10 .8 \\
13.9\end{array}$ & 2.8 & MK & & & & & $\begin{array}{lll}\mathrm{L} & & \\
\end{array}$ & 9 & \\
\hline 21 & Daiiti-Kashima & 35.8 & 142.7 & 62.3 & 348.8 & 20.1 & 348 & 10.7 & 3.1 & MK & & & & & $\mathrm{L}$ & 9 & \\
\hline 30 & Sio & 18 & 171.2 .2 & & 277.9 & & 37.2 & 3.6 & 2 & EK & & & & & $\mathrm{L}$ & & \\
\hline 31 & $\begin{array}{l}\text { Harvey } \\
\text { Tat }\end{array}$ & $17.8 \mathrm{r}=\mathrm{l}$ & 172.7 & 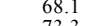 & 21.9 & $5^{-3}$ & 348.5 & 4.3 & 2.7 & LK & & & & & $\mathrm{L}$ & & \\
\hline 32 & $\begin{array}{l}\text { Thomas } \\
\text { Thlen }\end{array}$ & 17.3 & $\begin{array}{l}173.9 \\
174.1\end{array}$ & 73.3 & 324.2 & 5.3 & 8.2 & 3.5 & 2.5 & EK & $165 \mathrm{~L}$ & & & & $\mathrm{~L}$ & & 5 \\
\hline $\begin{array}{l}33 \\
34\end{array}$ & $\begin{array}{l}\text { Allen } \\
\text { Darwin }\end{array}$ & $\begin{array}{l}18.3 \\
22.1\end{array}$ & $\begin{array}{l}174.1 \\
171.6\end{array}$ & $\begin{array}{l}69.2 \\
39.9\end{array}$ & $\begin{array}{l}328.6 \\
316.8\end{array}$ & $\begin{array}{l}-1.2 \\
36.2\end{array}$ & $207.8^{8.8}$ & $\begin{array}{l}4.1 \\
1.9\end{array}$ & $\begin{array}{l}3.6 \\
2.4 \\
\end{array}$ & EK & & & & & $\mathrm{L}$ & & \\
\hline & & & & 43.4 & 316.6 & 31.5 & $205.9 \dagger$ & $2.0 / 0.9$ & & EK & $109 \mathrm{~F}$ & 15.5 & 5.9 & 55 & $\mathrm{~s}$ & 8 & 6 \\
\hline 35 & Unnamed & 21.2 & 173.8 & 84.4 & 3215 & 30.6 & 3.1 & $2.0 / 1.4$ & & & & 11.1 & 3.3 & 52 & $S$ & & \\
\hline 74 & $\begin{array}{l}Z 41 \\
\text { Z42 }\end{array}$ & $\begin{array}{l}28.8 \\
28.4\end{array}$ & $\begin{array}{l}148.4 \\
148.2\end{array}$ & $\begin{array}{l}55 \\
53\end{array}$ & $\begin{array}{r}19 \\
278\end{array}$ & $\begin{array}{l}9 \\
5\end{array}$ & $\begin{array}{l}334 \\
28\end{array}$ & $\begin{array}{l}1.8 \\
4.2\end{array}$ & 2.3 & MK & & & & & L & 10 & \\
\hline & & & & 59.9 & 292 & 6.1 & 17.2 & 4.111 .6 & ${ }_{4}^{2}$ & EK & & 7.9 & 2.7 & 59 & $\mathrm{~s}$ & & \\
\hline 75 & Z43 & 27.1 & 148.7 & 55.9 & 323.0 & -13.7 & 3.2 & 9.2 & 3.3 & & & & & & $\mathrm{~L}$ & & \\
\hline & & & & 57.1 & 334.1 & -11.3 & 357 & $8.4 / 5.1$ & & MK & $13.7 \mathrm{~K}$ & 6.7 & 2.5 & 93 & $\mathrm{~S}$ & 5 & 3 \\
\hline $\begin{array}{l}16 \\
77\end{array}$ & $\begin{array}{l}\text { Z44 } \\
\text { Makarov }\end{array}$ & $\begin{array}{l}22.8 \\
29.5\end{array}$ & $\begin{array}{l}146.7 \\
153.5\end{array}$ & $\begin{array}{l}60 \\
63.7\end{array}$ & $\begin{array}{r}306 \\
331.3\end{array}$ & $\begin{array}{l}-1 \\
64\end{array}$ & ${ }_{1}^{11}$ & & 1.8 & & & & & & & & \\
\hline & & & & 59.2 & 346.2 & -1.3 & 353.5 & 8.90 .2 .1 & & MK & $94 \mathrm{~A}$ & 2.9 & 0.9 & 101 & $\mathrm{~L}$ & 5 & 3 \\
\hline 78 & Miami & 21.7 & 161.9 & $\begin{array}{l}51.7 \\
589\end{array}$ & $\begin{array}{r}341.5 \\
59\end{array}$ & -30.8 & 0.3 & $\begin{array}{r}7.5 \\
81.47\end{array}$ & 2.6 & MK & & 65 & 1 & 116 & $\mathrm{~L}_{\mathrm{S}}$ & 3 & \\
\hline 79 & Birdseye & 20.9 & 165.7 & 58.6 & 342.3 & -20.4 & $\begin{array}{r}340.1 \\
1.8\end{array}$ & 年 13 & 8.1 & MK & & & & & $\mathrm{L}$ & i & \\
\hline 80 & Woods Hole & 21.2 & 166.5 & 55.2 & $\begin{array}{r}349.5 \\
3107\end{array}$ & -25.7 & 358.2 & $\begin{array}{r}11.2 \\
80.44\end{array}$ & 3.2 & & & 68 & 2 & 61 & $\mathrm{~L}_{\mathrm{S}}$ & $\frac{3}{5}$ & \\
\hline 81 & Unnamed & 19.4 & 165.9 & 58.4 & $\begin{array}{r}5.9 \\
5.9\end{array}$ & -20.3 & 349.5 & $\begin{array}{r}0.014 .4 \\
6.2\end{array}$ & 2.2 & MK & & 0.0 & & & $\begin{array}{l}\mathrm{S} \\
\mathrm{L}\end{array}$ & 3 & \\
\hline 82 & Unnam & & 162.4 & $\begin{array}{l}71 \\
57\end{array}$ & 281.3 & 13.7 & 16.7 & 1.6 & 5.5 & EK & & & & & $\mathrm{L}$ & 1 & \\
\hline 84 & Unnam & & $\begin{array}{l}159.3 \\
153.3\end{array}$ & 71.7 & 24 & -26 & & $\begin{array}{l}0.9 \\
1.8\end{array}$ & 9.5 & & & & & & $\begin{array}{l}\mathrm{L} \\
\mathrm{L}\end{array}$ & 1 & \\
\hline 85 & Campb & & 149 & 55 & 31 & 31.8 & $189.6 \dagger$ & 4.8 & 2.4 & EK & $>118 \mathrm{P}$ & & & & $\mathrm{I}$ & 1 & \\
\hline 86 & & 11.2 & 146.8 & 1.5 & 6.4 & -1.7 & 350.2 & 7.5 & 2.7 & ET & & & & & & 1 & \\
\hline 87 & Winchester & 10.3 & 156.7 & 55.8 & 296.6 & -29.8 & 22.1 & & 4.1 & & & 86 & 32 & 38 & & & \\
\hline 88 & Heezen & 8.8 & 163.2 & 57.4 & $\begin{array}{r}280 \\
340.3\end{array}$ & $\begin{array}{l}-253 \\
-41.3\end{array}$ & $\begin{array}{r}20.8 \\
1.7\end{array}$ & 5.4 & 3.4 & $\begin{array}{l}\text { EK } \\
\text { MK }\end{array}$ & & 8.6 & 3.2 & 30 & L & $\begin{array}{l}8 \\
1\end{array}$ & \\
\hline
\end{tabular}


Tanz. J. Sci. Vol 342008

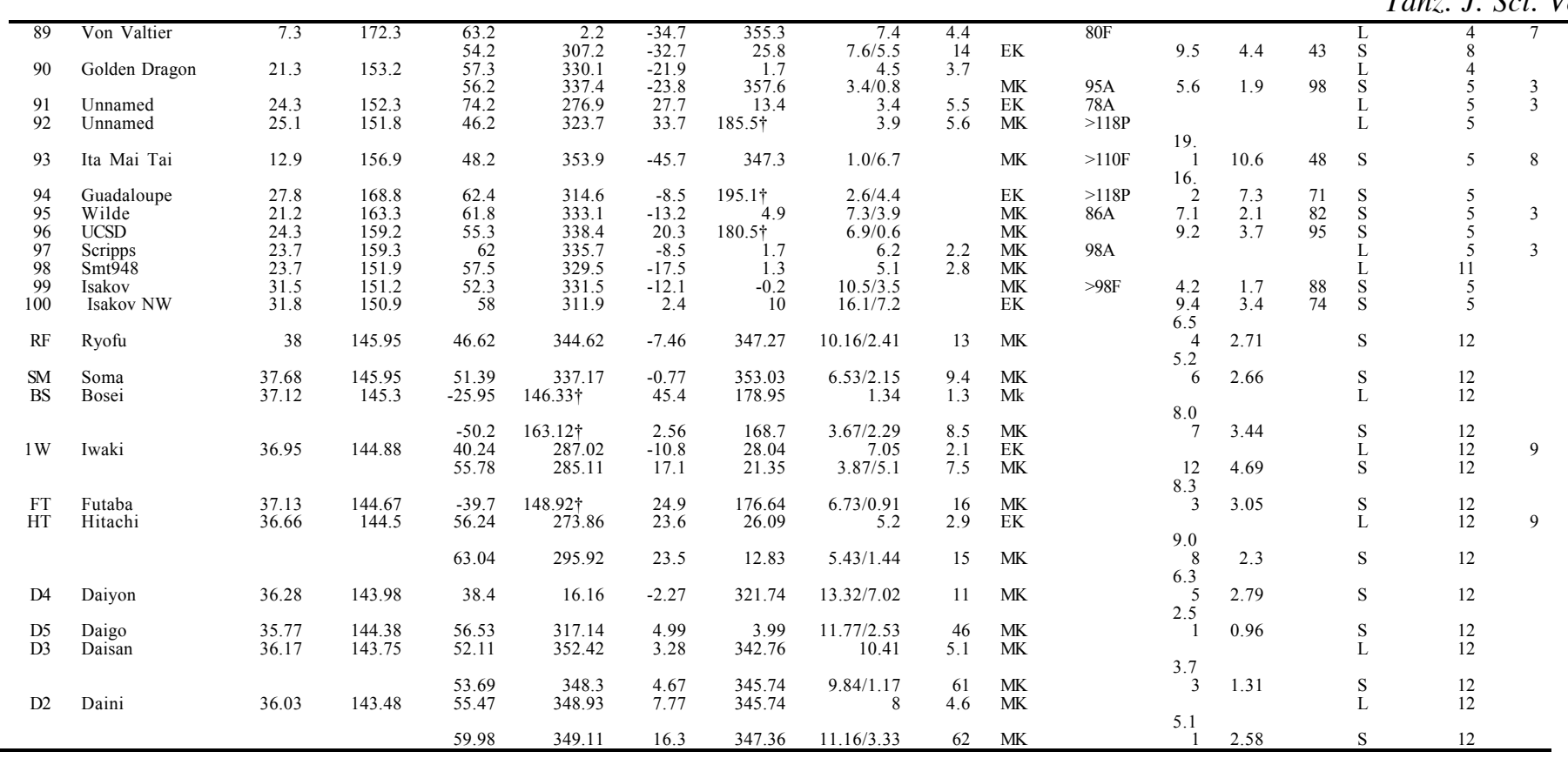

$\dagger$ Indicates reversed polarity

\section{Heading Abbreviations:}

Inc., inclination; Dec., declination; Inten., magnetization intensity (U, uniform; NU, nonuniform)

units in amperes/meter, GFR, goodness-of-fit ratio; Error Ellipse, 95\% confidence region; Maj,

major semi-axis length (in degrees) ; Min, minor semi-axis length (in degrees); $A z$, azimuth of

major semi-axis (degrees clockwise from north).

Type, inverse technique; L, least squares minimization; S, seminorm minimization; Ref, reference number (see below) 


\section{Age Abbreviations:}

Paleomagnetic ages: ET, Early Tertiary; $L K$, Late Cretaceous; $M K$, mid-Cretaceous; EK, Early Cretaceous-Late Jurassic. Other age types: $A,{ }^{40} \mathrm{Ar}-{ }^{39} \mathrm{Ar}$; K, Potassium-Argon; F, Fossil; $L$,

Lithospheric flexure; $P$, Magnetic polarity.

\section{Paleomagnetic References:}

(1) Sager, 1983; (2) Francheteau et al., 1969; (3) Harrison et al., 1975; (4) Sager and Pringle,

1988; (6) Uyeda and Richards, 1966; (7) Yamazaki, 1988; (8) Hildebrand and Parker, 1987; (9)

Ueda, 1985; (10) Vacquier and Uyeda, 1967; (11) Ueda, 1998; (12), Masalu et al., 1997.

\section{Age References:}

(1) Sager and Pringle, 1988; (2) Yamazaki, 1988; (3) Ozima et al., 1983; (4) Saito and Ozima,

1977; (5) Watts et al., 1980; (6) Harrison et al., 1975; (7) J. A. Haggerty, personal

communication, 1982; (8) Baltuck et al., 1986; (9)Masalu et al., (2001). 


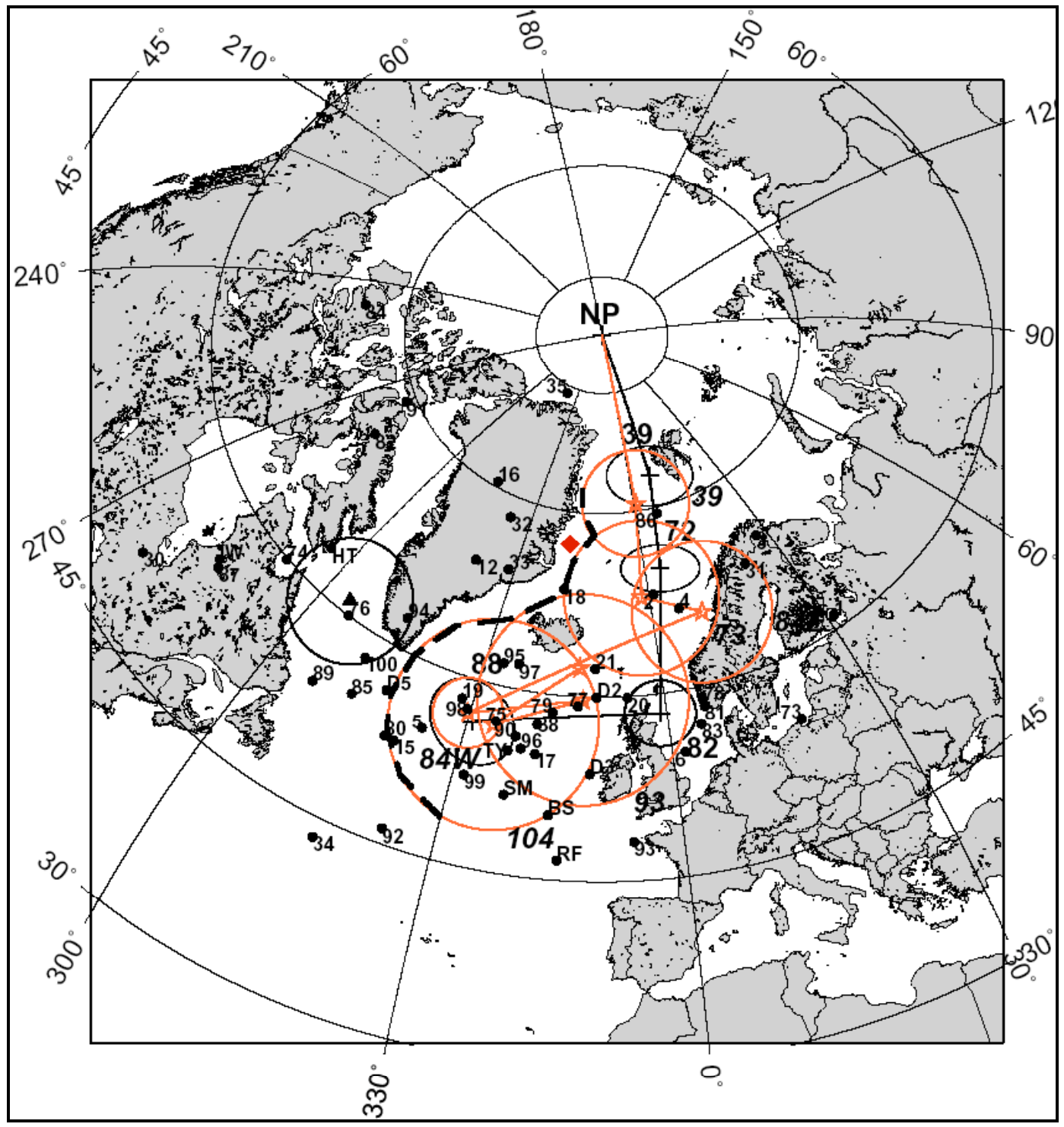

Figure 2: $\quad$ The known Pacific Apparent Polar Wonder Path (Sager and Pringle 1988) shown by the black solid line with its poles locations indicated by crosses. Black circles around them are pole's $95 \%$ confidence and big numbers near the circles indicate the age of the pole. The grey solid line is the new Pacific APWP of Sager and Koppers (2000) with its poles indicated by stars. Grey circles around the stars are pole's $95 \%$ confidence and big italic numbers near the circles indicate the age of the pole. The diamond indicates the pole for Chron C33r (79-83 Ma) of Sager (2003). Poles of all known seamounts on seafloor older than M1 are shown by solid circles. Seamounts details as in Table 1. The pole indicated by a solid triangle is derived from all seamounts considered to be of Jurassic-Early-Cretaceous age (left of the thick dashed line). 


\section{RESULTS}

Northward drift amounts of the seamounts that remained were found to vary from $0.7^{\circ}$ to $33.3^{\circ}$ (Fig. 3). The seamounts were divided into two groups depending on their northward drift amounts: the first group here referred to as $\mathbf{A}$, with northward drift amounts less than $15^{\circ}$ (shown by solid diamonds), and the other group here referred as B with northward drift amounts of $18^{\circ}$ and above (shown by solid circles). Because group A consists of seamounts with relatively smaller amounts of northward drift than those in group B, seamounts in group $\mathbf{A}$ are relatively older than seamounts in group B.

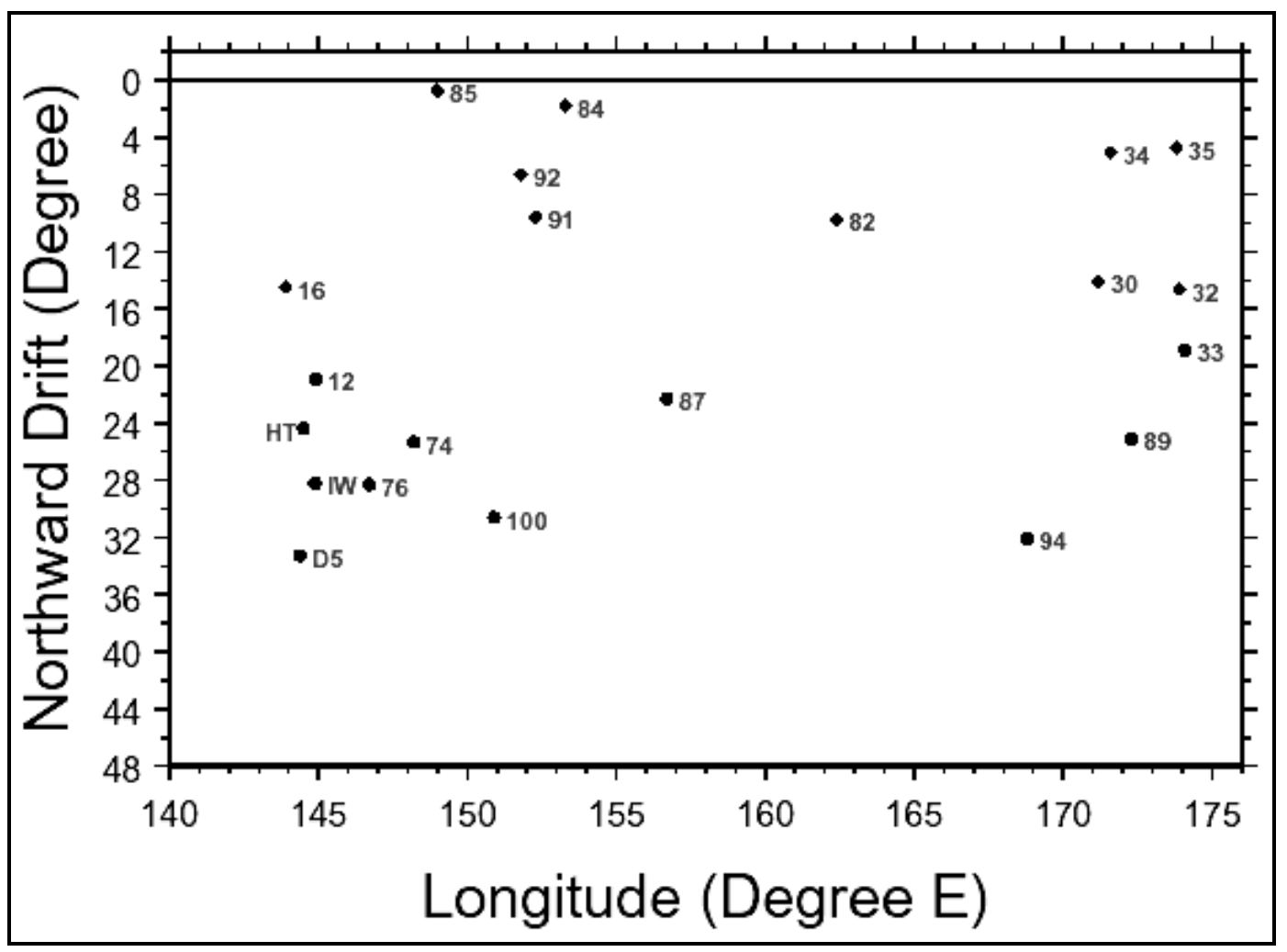

Figure 3: Northward drift of seamounts thought to be Jurassic-Early-Cretaceous in age as isolated in Figure 2 plotted against the seamount's longitudinal location. Seamounts details as in Table 1.

Table 2 shows seamounts within the two groups, $\mathbf{A}$ and $\mathbf{B}$, which have age constrains. Comparing Fig. 3 and Fig. 4 shows that, the poles of Jurassic to Early-Cretaceous seamounts that remained cluster into two groups: the northern cluster between $70^{\circ} \mathrm{N}$ and $75^{\circ} \mathrm{N}$, and the southern cluster between $50^{\circ} \mathrm{N}$ and $65^{\circ} \mathrm{N}$ that correspond consistently with groups $\mathbf{A}$ and $\mathbf{B}$, respectively. There are, however, a few exceptions. Poles for seamounts $30,34,85$ and 92 which belong to group $\mathbf{A}$ fall within and far to the south of the southern cluster (Fig. 4) instead of falling within the northern cluster as it would be expected based on their northward drift amounts (Fig. 3). Seamounts 34, 85 
and 92 are reversely magnetized and the apparently inconsistent location of their poles may be due to effect of significant amounts of magnetic polarity overprint or viscous magnetization of the seamounts (Sager and Pringle 1988, Masalu et al.
1993). For seamount 30, the apparently inconsistent location of its pole may be due to poor inversion. The seamounts might also have a different/younger age. These seamounts will not be considered further.

Table 2: Age constraints for Jurassic to Early-Cretaceous seamounts

\begin{tabular}{|c|c|c|c|c|}
\hline Group/Pole & ID & $\begin{array}{l}\text { Name of } \\
\text { seamount }\end{array}$ & $\begin{array}{l}\text { Age } \\
\text { (Ma) }\end{array}$ & Constraints \\
\hline \multirow{5}{*}{$\mathbf{A}$} & 16 & Takuyo-Daini & $98-144$ & $\begin{array}{l}\text { Guyot topped by Albian - Aptian corals } \\
\text { (Matthews et al. 1974); Seafloor age is M16 } \\
\text { (144 Ma). }\end{array}$ \\
\hline & 32 & Thomas & -162 & $\begin{array}{l}\text { Thin elastic plate thickness model implies age } \\
\text { close to that of seafloor (Watts et al. 1980); } \\
\text { Seafloor is about M25 (Winterer \& Metzler } \\
\text { 1984) }\end{array}$ \\
\hline & 34 & Darwin & $118-157$ & $\begin{array}{l}\text { Reversed polarity indicates age of M0 (118 Ma) } \\
\text { or older; Capped with Albian - Aptian corals } \\
\text { (Ladd et al. 1974); Seafloor age is M23 (157 } \\
\text { Ma). }\end{array}$ \\
\hline & 85 & Campbell & $118-161$ & $\begin{array}{l}\text { Reversed polarity indicates age of M0 (118 Ma) } \\
\text { or older; Seafloor age is M25 (161 Ma). }\end{array}$ \\
\hline & 92 & Unnamed & $118-167$ & $\begin{array}{l}\text { Reversed polarity indicates age of M0 (118 Ma) } \\
\text { or older; Seafloor age slightly older than M29 } \\
(167 \mathrm{Ma}) \text {. }\end{array}$ \\
\hline \multirow{4}{*}{ B } & 12 & Erimo & $104-130$ & $\begin{array}{l}{ }^{40} \mathrm{Ar}^{39} \mathrm{Ar} \text { age of } 104 \pm 9 \mathrm{Ma} \text { (Takigami et al. } \\
\text { 1989); Elastic plate thickness model implies } \\
\text { seamount age same as seafloor age, i.e., M8 } \\
(130 \mathrm{Ma}) \text { (Yamazaki 1988). }\end{array}$ \\
\hline & 94 & Guadaloupe & $118-139$ & $\begin{array}{l}\text { Reversed polarity indicates age of M0 (118 Ma) } \\
\text { or older; Seafloor age is M13 (139 Ma). }\end{array}$ \\
\hline & HT & Hitachi & $127-136$ & $\begin{array}{l}\text { Reconstruction to of the flat top of the seamount } \\
\text { to sea level give an age of } 127 \mathrm{Ma} \text { (Masalu et } \\
\text { al. } 2001 \text {; Seafloor age is } 136 \mathrm{Ma} \text {. }\end{array}$ \\
\hline & IW & Iwaki & $126-136$ & $\begin{array}{l}\text { Reconstruction to of the flat top of the seamount } \\
\text { to sea level give an age of } 126 \mathrm{Ma} \text { (Masalu et } \\
\text { al. 2001); Seafloor age is } 136 \mathrm{Ma} \text {. }\end{array}$ \\
\hline
\end{tabular}




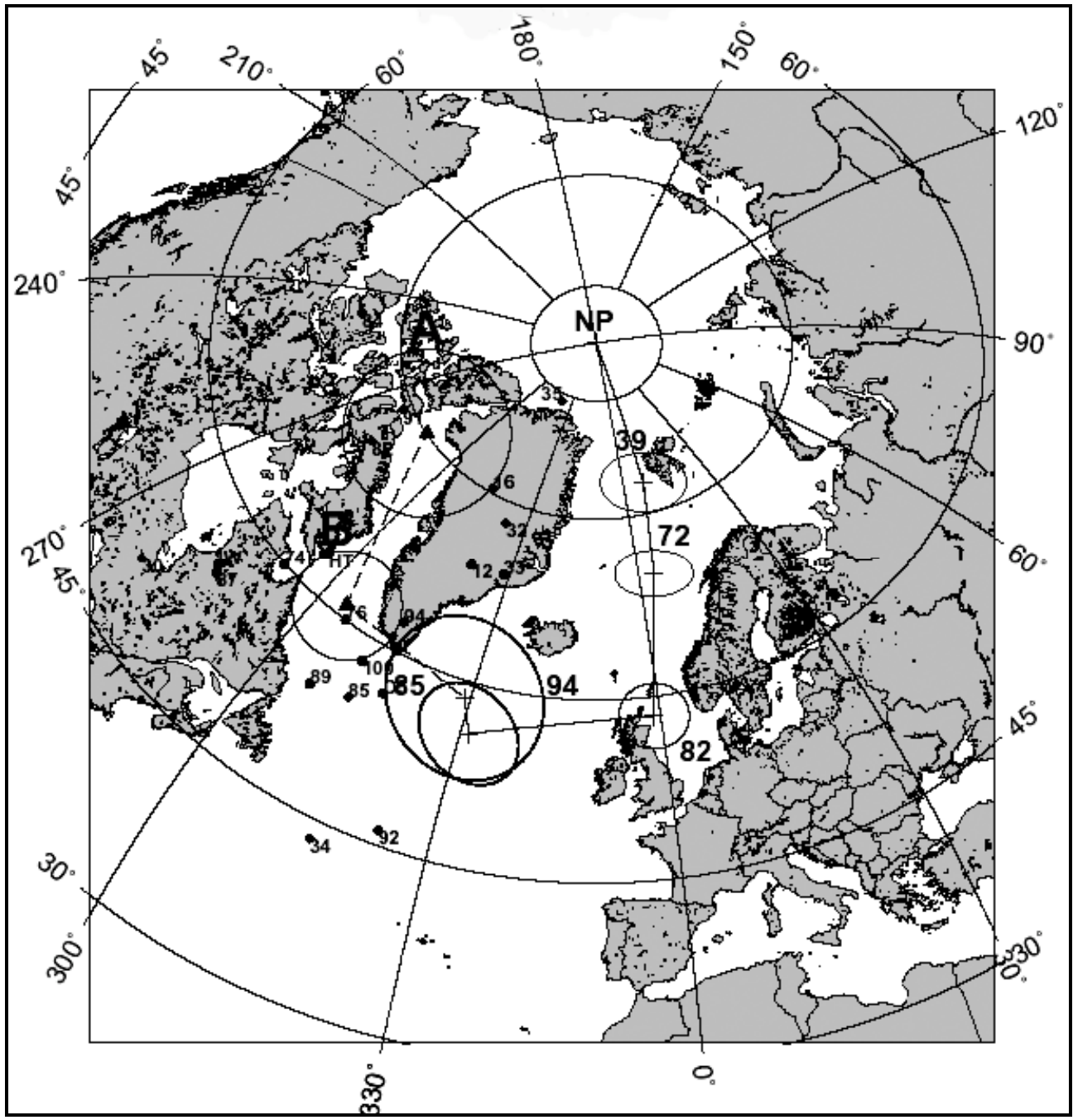

Figure 4: The extended Pacific Apparent Polar Wonder Path (APWP) showing the known part of the APWP of (Sager and Pringle 1988) shown by solid line, crosses to indicate pole locations, circles around them to mark the pole's $95 \%$ confidence and the big numbers near the circles to indicate the age of the pole. The extended part of the Pacific Apparent Wonder path is indicated by a dashed line and its poles, $\mathbf{A}$ and $\mathbf{B}$ by solid triangles. Poles of all seamounts on seafloor older than M1 that were used to compute pole $\mathbf{A}$ are indicated by solid diamonds while those used to compute pole $\mathbf{B}$ are indicated by solid circles. Seamounts details as in Table 1.

The mean pole for each cluster (shown by solid triangle, Fig. 4) was computed. For the northern cluster poles of $16,32,35,82$, 84 , and 91 seamounts were used. The mean pole for this cluster, pole $\mathbf{A}$, is at $75.01^{\circ} \mathrm{N} / 287.5^{\circ} \mathrm{E}\left(\alpha_{95}=6.9^{\circ}\right)$. To compute the mean pole for the southern cluster, pole $\mathbf{B}$, poles of seamounts $12,33,74,76,87$, $89,94,100$, D5, HT, and IW were used. The obtained mean pole is at 
$61.0^{\circ} \mathrm{N} / 304.7^{\circ} \mathrm{E}\left(\alpha_{95}=4.5^{\circ}\right)$. This pole is insignificantly different with the Jurassic to Early-Cretaceous pole obtained by Hildebrand and Parker (1987) which was obtained based on five seamounts residing on Pacific seafloor older than $150 \mathrm{Ma}$. Seamounts with age constraints (Table 2) were then used to estimate approximate ages of these poles. For pole B four seamounts, 12, 94, HT and IW have age constraints (Table 2). All seamounts reside on seafloor with an age less than $140 \mathrm{Ma}$. A simple mean computed from the mean ages of these seamounts gives a mean age of $127 \mathrm{Ma}$ for pole $\mathbf{B}$. For pole A, five seamounts have age constraints. All five seamounts as opposed to pole B, reside on seafloor older than 140 Ma. A mean pole computed based on the mean ages of the two seamounts, seamounts 16 and 32 that were used in estimation of the pole A, gives an age of $142 \mathrm{Ma}$ for pole A. The newly computed poles were connected to the known Mid-Cretaceous to Present part of the Pacific APWP (Fig. 4). The results indicate that, the Pacific plate drifted southward during the Jurassic to Early-Cretaceous period.

\section{DISCUSSION}

The correspondence between APWPs and hotspot tracks based on available plate motion models is only poorly understood. However, a significant change in the direction of the APWP is often interpreted as an indication of a major shift in plate motion (Gordon et al. 1984) and it has been suggested that the two are linked (Sager. and Pringle 1988). For instance, for the Pacific plate, the 82 Ma APWP bend corresponds to the 75 to $70 \mathrm{Ma}$ change in plate motion (Sager and Pringle 1988). Similarly, the 39 Ma APWP bend may correspond to the 47 Ma change in plate motion. Absolute motion of the Pacific plate has recently been studied extensively (Henderson 1985, Engebretson et al. 1985, Duncan and Clague $1985)$. The younger trajectory (0 to $\sim 78 \mathrm{Ma})$ of the motion of this plate manifested by the Hawaii Emperor Chain (coupled with the availability of reliable dates) is well constrained, while the older trajectory is poorly constrained (Jarrard and Sasajima 1980, Sager and Pringle 1988). The major problem with older trajectory (prior to -80 $\mathrm{Ma}$ ) is the scarcity of reliable dates and clear hotspot tracks for that period. Consequently, models of absolute motion for the Pacific plate show significant variations for the period prior to about $80 \mathrm{Ma}$. Nevertheless, advanced research and the availability of many different types of scientific data, have allowed for better models of absolute motion of the Pacific plate.

The correspondence between the Pacific plate absolute motion models and the APWP is compared using the model of absolute motion of Henderson (1985) and the APWP2 of Sager and Pringle (1988) which have been extended by adding the two poles estimated in the present work. Based on the Henderson (1985) model, the Pacific plate shows changes in absolute plate motion direction at about $44 \mathrm{Ma}, 75$ to $80 \mathrm{Ma}, 95$ to $100 \mathrm{Ma}$, and at $130 \mathrm{Ma}$. These changes of plate motion appear to correspond with changes in direction of the APWP at $39 \mathrm{Ma}$, $82 \mathrm{Ma}, 85$ to $94 \mathrm{Ma}$, and $\sim 127 \mathrm{Ma}$ (pole B), respectively. The consistency of the timing of the change of the Pacific plate motion at $130 \mathrm{Ma}$ and the suggested timing of the change of the APWP based on pole B $(\sim 127$ $\mathrm{Ma})$, suggests that pole $\mathrm{B}$ may indeed be about 130 - $127 \mathrm{Ma}$.

\section{CONCLUSION}

An attempt to delineate the Jurassic to Mid-Cretaceous part of the Pacific APWP using a systematic approach which does not depend on availability of reliable dates of paleomagnetic data have been done. Two new poles were computed: pole $\mathbf{A}$ which is at $75.01^{\circ} \mathrm{N} / 287.5^{\circ} \mathrm{E}\left(\alpha_{95}=6.9^{\circ}\right)$ and the other pole, $\mathbf{B}$, which is at $61.0^{\circ} \mathrm{N} / 304.7^{\circ} \mathrm{E}$ $\left(\alpha_{95}=4.5^{\circ}\right)$. Pole $\mathbf{B}$ is relatively younger than pole $\mathbf{A}$ and it is estimated to be about 130 - $127 \mathrm{Ma}$. These results indicate that the Pacific plate drifted southward during the Jurassic to Early-Cretaceous period. Changes of plate motion and the APWP appear to 
correspond. It is hoped that the results presented here will play an important role in future research directions in reconciling models of absolute plate motion and APWPs.

\section{REFERENCES}

Cox A and Gordon RG 1984 Paleolatitudes determined from paleomagnetic data from vertical cores. Rev. Geophys. Space Phys. 22: 47-72.

Duncan A and Keller RA 2004 Radiometric ages for basement rocks from the Emperor Seamounts, ODP Leg 197. Geochem. Geophys. Geosyst. 5: doi:10.1029/2004GC000704.

Duncan RA and Clague DA 1985 Pacific plate motion recorded by linear volcanic chains. In Nairn AEM, Stehli FG and Uyeda S (eds) The Ocean Basins and Margins, Vol. 7A, Plenum Publishing, New York.

Engebretson DC, Cox A and Gordon RG 1985 Relative motions between oceanic and continental plates in the Pacific Basin, GSA Special Paper / Geol. Soc. Amer. 206.

Fisher RA 1953 Dispersion on a sphere. Proc. Roy. Soc. Lond. A217: 295-305.

Gordon RG, Cox A and O'hare S 1984 Paleomagnetic Euler poles and the apparent polar wander and absolute motion of North America since the Carboniferous. Tectonics 3: 499-537.

Henderson LJ 1985 Motion of the Pacific plate relative to the hotspots since the Jurassic and model of oceanic plateaus of the Farallon plate. PhD. Dissertation, Northwestern University, Evanston.

Hildebrand JA and Parker RL 1987 Paleomagnetism of Cretaceous Pacific seamounts revisited. J. Geophys. Res. 92: 12695-12712.

Jarrard RD and Sasajima S 1980 Paleomagnetic synthesis for southeast Asia: constraints on plate motions. In Hayes DE (ed) The Tectonic and Geologic Evolution of Southeast Asian
Seas and Islands, Geophys. Mon. Ser. Vol. 23, AGU, Washington, D. C.

Ladd HS, Newman WA and Sohl NF 1974 Darwin guyot, the Pacific's oldest atoll. Proc. $2^{\text {nd }}$ Int. Symp. Coral Reefs 513-522.

Larson RL and Lowrie W 1975 Paleomagnetic evidence for motion of the Pacific plate from Leg 32 basalts and magnetic anomalies. Initial Report of the Deep Sea Drilling Project 32: 571-577.

Masalu DCP, Tamaki K and Kobayashi K 1993 Paleomagnetism of the Joban seamount chain, northwestern Pacific. $J$. Geomagn. Geoelect. 45: 503 -534.

Masalu DCP 1994 Paleomagnetism of the Joban Seamount Chain: Its Origin and Tectonic Implications for the Pacific Plate. D. Sci. Thesis, Department of Earth and Planetary Physics, University of Tokyo.

Masalu DCP, Tamaki K and Sager W 1997 Paleomagnetism of the Joban Seamount Chain: Its Origin and Tectonic Implications for the Pacific Plate. $J$. Geophys. Res. 102: 5145-5155.

Masalu DCP, Ogawa Y and Kobayashi K 2001 Bathymetry of the Joban Seamount Chain, Northwestern Pacific. Mar. Geol. 173: 87-96.

Matthews JL, Heezen BC, Catalano R, Coogan A, Tharp M, Natland J and Rawson M 1974 Cretaceous drowning of reefs on Mid-Pacific and Japanese guyots. Science 184: 462-464.

Nakanishi M, Tamaki K and Kobayashi K 1992 A new Mesozoic isochron chart of the Northwestern Pacific ocean: Paleomagnetic and tectonic implications. Geophys. Res. Lett. 19: 693-696.

Parker RL, Shure L and Hildebrand JA 1987 The application inverse theory to seamount magnetism. Rev. Geophys. 25: 17-40.

Plouff D 1976 Gravity and magnetic fields of polygonal prisms and applications to magnetic terrain corrections. Geophys. 41: 727-741. 
Sager WW 2003 Chron C33r paleomagnetic pole for the Pacific Plate. Geophys. Res. Lett. 30: doi:10.1029/2003GL017964.

Sager WW and Koppers AAP 2000 Late Cretaceous Polar Wander of the Pacific Plate: Evidence of a Rapid True Polar Wander Event. Science 287: 455-459.

Sager WW and Pringle MS 1988 MidCretaceous to early Tertiary Apparent Polar Wander Path of the Pacific Plate. J. Geophys. Res. 93: 11753-11771.

Sager WW 1992 Seamount age estimates from paleomagnetism. and their implications for the history of volcanism on the Pacific plate. In Keating $\mathrm{BH}$ and Bolton B (eds) Geology and Offshore Mineral Resources of the Central Pacific Basin, Circum-Pacific Council for Energy and Mineral Resources. Earth Sci. Ser. 14, 21-37.

Steinberger B, Sutherland R and O'Connell RJ 2004 Prediction of Emperor-Hawaii Seamount Locations from a Revised Model of Global Plate Motion and Mantle Flow. Nature 430: 167-173.

Takigami Y, Kaneoka I, Ishii $\mathrm{T}$ and Nakamura Y $1989{ }^{40} \mathrm{Ar}-{ }^{39} \mathrm{Ar}$ ages of igneous rocks recovered from Diichi-Kashima and Erimo seamounts during the KAIKO project. $J$. Palaeogeog., Palaeoclim. Palaeoecol. 71: 71-81.
Talwani M 1965 Computation with the help of a digital computer of magnetic anomalies caused by bodies of arbitrary shape. Geophysics 30: 797-817.

Tarduno JA 2007 On the Motion of Hawaii and Other Mantle Plumes. J. Chem. Geol. 241: 234-247.

Tarduno JA, Duncan RA, Scholl DW, Cottrell RD, Steinberger B, Thordarson T, Kerr BC, Neal CR, Frey FA, Torii M and Carvallo C 2003 The Emperor Seamounts: Southward Motion of the Hawaiian Hotspot Plume in Earth's Mantle. Science 301: 1064-1069.

Watts AB, Bodine JH and Ribe NM 1980 Observation of flexure and the geological evolution of the Pacific ocean basin. Nature 283: 532-537.

Wessel P, Harada Y and Kroenke LW 2006 Toward a self-consistent, high-resolution absolute plate motion model for the Pacific. Geochem. Geophys. Geosys. 7: Q03L12, doi:10.1029/2005GC001000.

Winterer EL and Metzler CV 1984 Origin and subsidence of guyots in the Mid Pacific Mountains. J. Geophys. Res. 89: 9969-9979.

Yamazaki T 1988 Magnetization of Erimo seamount. J. Geomagn. Geoelect. 40: 715-728. 